\title{
Combined Deep Transverse Friction and Muscle Energy Technique on Mechanical Neck Pain: Article Review
}

\author{
I Putu Mahendra Putra ${ }^{1 *}$, Made Hendra Satria Nugraha ${ }^{2}$, Ni Wayan Tianing ${ }^{3}$
}

'Bachelor of Physiotherapy and Physiotherapy Profession Study Program, Faculty of Medicine, Universitas Udayana 2Physiotherapy Department, Faculty of Medicine, Universitas Udayana

${ }^{3}$ Biochemistry Department, Faculty of Medicine, Universitas Udayana

*Corresponding author: I Putu Mahendra Putra; Bachelor of Physiotherapy and Physiotherapy Profession Study Program, Faculty of Medicine, Udayana University ivomahendra8@gmail.com

Received : 2020-02-22 Accepted : 2020-04-20 Published: 2020-05-15

\section{ABSTRACT}

Introduction: Since mechanical neck pain has become a common problem, physiotherapists' role in reducing symptoms caused by mechanical neck pain varies such as muscle energy technique and deep transverse friction. Based on the references, mechanical neck pain defined as a condition non-radicular or local pain which increased pain intensity during movement. The study aims to understand whether deep transverse friction and muscle energy technique are effective to reduce pain the mechanical neck pain.

Method: The study used the secondary data through article review which focuses on the journals and articles related to the muscle energy technique and deep transverse friction in the mechanical neck pain.

Results: The application and method of muscle energy technique are aimed at normalizing the structure of dysfunctional tissue, such as the shortening of muscles, which indirectly gives a direct effect on the joint. It is suggested as a method to improve the mobility of the joint. Besides, to reduce pain through pain modulation, deep transverse friction was applicable to provide it at the level of the supra-spinal to release endorphins, enkephaline, and cortisol.

Conclusion: Either muscle energy technique or deep transverse friction are shown a good effect to reduce pain, neck disability, and increase ROM of the cervical joint in patients with mechanical neck pain. Besides, deep transverse friction has also reducing spasm/ tightness at the cervical joint level in patients with mechanical neck pain.

Keywords: deep transverse friction, mechanical neck pain, muscle energy technique

Cite this Article: Putra, I.P.M., Nugraha, M.H.S., Tianing, N.W. 2020. Combined Deep Transverse Friction and Muscle Energy Technique on Mechanical Neck Pain: Article Review. Physical Therapy Journal of Indonesia 1(1): 17-22.

\section{INTRODUCTION}

The neck is the most mobile and most widely used region. ${ }^{1,2}$ As a result of frequently used and frequently moved, mechanical loads can occur on the neck associated with changes in head position and changes in cervicothoracic posture. ${ }^{2}$ Biomechanical changes in the cervical will indirectly give effect to the structure of the cervical itself, where the cervical will get a load with uneven spread and the impact will be greater effect the lower cervical because the lower cervical will get the load generated by the mechanical changes. This will cause pain in the neck (nape). ${ }^{2}$

Since neck pain has become a common problem, estimated that the incidence of neck pain is around $15 \% .{ }^{3,4,5}$ Neck pain has also become the second most common disease after low back pain which occurs in the general population and musculoskeletal practice. ${ }^{3}$ Neck pain occurs in approximately $67 \%$ in adults aged 20-69 years. ${ }^{4}$ In a study conducted by Hoy et al. (2010) it was also stated that the estimated number of incidents in one year ranged up to $10.4 \%$ until $21.3 \%$ with higher incidence rates for workers who use computers. The incidence of neck pain generally occurs with a higher number in females and is higher occur in the developed countries and urban areas. Some factors influencing the duration and process of neck pain such as environmental and personal factors. ${ }^{5}$

In Indonesia, the incidence of cervical pain continues to increase. Approximately $16.6 \%$ of adults complain of discomfort in the cervical region, even $0.6 \%$ starts from a feeling of discomfort in the cervix that changes to severe cervical pain. The references also found that it is increasing with age and is more commonly occur in women than in men, with a comparison of 1.67: $1.6 .^{6}$

Neck pain categories are varied and many ways to decide the category of neck pain. One of the reference state that it depends on the duration of pain that is felt by the patient ( $<6$ weeks is acute level, $\leq 3$ months is sub-acute level, and $>3$ months is chronic level), Mechanical neck pain or nonspecific neck pain, refers to neck pain caused by a lesion in the spine or neck supporting structures, such as minor strains and sprain in the ligaments and cervical muscles, as a result of trauma, posture errors, work that can cause strain, also the position of the flexed head for a long period time such as 
when reading, writing, watching television and using a computer. ${ }^{6,7}$

There are assessments that can be done to diagnose mechanical neck pain. One of them is by physical examination. Some physical examination that can be done is an examination of the range of motion of joints, muscle strength and palpation. The range of joint motion is given because the known mechanical neck pain sufferers tend to decrease the joint range of motion. Measurement of muscle strength is done because usually, patients with neck pain have weaker muscle strength when compared to healthy people. Palpation is done to check the trigger or tender point. ${ }^{8}$

Mechanical neck pain is a pain that is nonradicular, so for the examination, we can use a radiculopathy provocation test. If the provocation test results are negative (no pain spreads), then it can be said the pain felt by the patient is a pain caused by mechanical neck pain. Some tests that can be performed to provoke radiculopathy are namely Spurling's test, neck traction or distraction test, shoulder abduction test, and Valsalva's maneuver test. In addition, negative results on the ULTT test can also indicate mechanical neck pain. ${ }^{9}$ As comparative diagnoses are transient ischemic attack or cerebral vascular accident, myelophaty, rheumatoid arthritis, thoracic outlet, and discitis. ${ }^{10}$

A radiculopathy provocation test can be confirmed whether the patients are indicated mechanical neck pain or not. ${ }^{9}$ Red flags are also important to be considered to suspect other pathologies. Several red flags must be considered in the examination and diagnosis of mechanical neck pain. Red flags that may indicate the presence of myelopathy are abnormal gait patterns, hand weakness, and decreased bowel and bladder function. Red flags also help us to know whether someone has to indicate cancer, infection, inflammation fever, weight loss without cause, sleep disturbances, lymphadenopathy, and other infectious diseases. Red flags also can indicate the severity of the trauma or skeletal injury, a neck surgery in the past, and osteoporosis risk factors, such as premature menopause and systemic steroid use. $^{9}$

Prostaglandin levels can also be used as criteria for diagnosing mechanical neck pain. Inflammation is the immune system's response to infection and injury. ${ }^{11}$ Inflammatory mediators such as cytokines, prostaglandins, and neuropeptides, will increase in the dorsal root ganglion during inflammation. ${ }^{12}$ Besides, to increase neural excitability and behavioral sensitivity for inflammation, type of prostaglandins E2 or PGE2 has been identified as a key mediator. The G-protein receptor shows that
EP2 is involved in the pathophysiology of painful joint conditions. ${ }^{12}$

Problems in the neck are not problems that can be life-threatening, but problems in the neck can cause pain and stiffness that cause disability and limitations in work and require medical treatment. ${ }^{1}$ Common therapies used to reduce mechanical neck pain symptoms are soft tissue mobilization.

MET is a method of soft tissue mobilization which is combining isometric contraction and direction and control of movement precisely to the patient. The use of isometric contraction in the muscle energy technique is intended to restore the function of the musculoskeletal system and reduce pain. MET application is intended to restore the structure of the soft tissue to normal, and give indirect effects to the joint associated with the muscles that experience dysfunction, so that muscle energy technique can be used to normalize joint mobility in soft tissue structures that experience dysfunction. ${ }^{2}$ Besides muscle energy technique, deep transverse friction can also use. Deep transverse friction is one of the soft tissue mobilization methods with specific tissue massage techniques that aim to maintain soft tissue mobility such as ligaments, tendons, and muscles and prevent scar tissue formation. Besides, deep transverse friction can also provide analgesic effects and add muscle relaxation. ${ }^{13}$ Both of these methods can be used to reduce the neck pain symptoms.

\section{METHOD}

This study has using secondary data through article review which focuses on the journals and articles related to the muscle energy technique and deep transverse friction in the mechanical neck pain.

\section{RESULTS}

Soft tissue mobilization is one of the therapeutic manuals with soft tissue mobilization techniques that are said to be effective in reducing vertebral complaints such as mechanical neck pain. MET is a manipulation technique in the osteopathic soft tissue level which has aim to restore the normal function of the musculoskeletal system and reduce pain by combining precise isometric control, direction, and contraction. Technique to apply MET is by contraction for 10 seconds, then continued with stretching for 30 seconds with a minimum resistance of $20 \%$ and repetition 5 times. The goal of being given a $20 \%$ detention is to produce contractions without further damage from the tissue that has lesions. ${ }^{14}$

The MET is also useful to help repair joint mobilization. This effect occurs through the effects 
of muscle energy technique on dysfunctional tissue structure. It is intended to re-normalize tissue structures that experience dysfunction, such as shortening of the muscles, which will indirectly have a direct effect on the joints that have a connection with the muscles that are shortened. ${ }^{2}$ Muscle energy technique is effective in increasing the range joint motion, reduce pain, ${ }^{2,14,15}$ and eliminate trigger points in the case of myofascial pain syndrome. ${ }^{14}$

Research conducted by Phadke et al. (2011) showed that MET was effective in reducing pain and disability in mechanical neck pain. This is also supported by research by Arthawan et al (2017) which states that the MET is effective in increasing the range of joint motion, reducing pain, and eliminating trigger points in cases of myofascial pain syndrome. Besides, a study by Wadee (2017) suggests that application muscle energy technique including post isometric relaxation techniques can reduce disability, improve function, and improve the ROM of patients with mechanical neck pain.

Muscle energy technique is effective in increasing the range of motion of the joints because it has the principle of manipulating motion in a subtle way involving the power of movement of the patient. ${ }^{14}$ Muscle energy techniques can increase the range of motion in the movement of extension, rotation, and lateral flexion in the cervical region. The effect of increasing cervical joint motion is due to the mechanism of PIR (post-isometric relaxation) and RI (reciprocal inhibition). ${ }^{2,14}$

Karel Lewit was developing Post isometric relaxation which can reduce muscle tone, or muscle group, after a short isometric contraction. The application of the concept of post isometric relaxation is done by utilizing isometric contractions. The muscle of the hyper tone will be stretched to the first degree of limitation of the sphere of joint motion. The therapist will give the prisoner in the opposite direction, and the patient is asked to do isometric contractions by resisting the therapist's resistance for 5-10 seconds. The isometric contraction given is $20 \%$. Then, the muscle will be stretched gently to increase muscle flexibility. This procedure is repeated 2 or 3 times. Besides, reciprocal inhibition involves the response of the physiological antagonistic muscles which isometrically being contracted. When the muscles are isometrically contracted, their antagonist muscles will be inhibited and will decrease muscle tone. The application of the concept of reciprocal inhibition is done by utilizing antagonistic muscle contractions. Muscles that have lesions are positioned in the middle of the total degree of joint motion. Then, we ask patient to contract in a limited direction while the therapist gives the opposite direction (isometric) or even allows movement towards him (isotonic). This is followed by relaxation of the patient and also exhalation. At the same time, the therapist is passively stretching in a limited direction with new degrees of limitation. This procedure is repeated 3 - 5 times. $^{15}$

\section{DISCUSSION}

Mechanical neck pain is defined as a condition of a person experiencing non-radicular or local pain with increased pain intensity during movement and when emphasized in the cervical region., ${ }^{2,16}$ Conditions of facet joint dysfunction and minor strain/sprain in the ligaments and muscles also can be regarded as mechanical neck pain. Neck pain is regarded as a mechanical neck pain if both at the time of physical examination and the history of the disease are not found any symptoms or signs of pathological pain such as myelopathy, neoplasm, fracture, systemic disease, and neurological signs (motor / sensory disorders, tendon reflex). The pain sensation of mechanical neck pain does not radiate to the upper limb area. The upper, neck and occipital back is a frequent place of pain in mechanical neck pain cases. ${ }^{2}$

The biggest contributing factor to the occurrence of mechanical neck pain is the habit of poor posture when doing a job or doing activities. Some jobs also have a relationship as a mechanical neck pain occurrence factor. Mechanical neck pain has a high chance of occurring in this type of work that requires repeated static postures for a long time. Some previous studies have shown that the type of work that requires a person to be in a static position such as craftsmen, typists, and tailors have a strong influence on mechanical neck pain. Work with heavy and repetitive intensity and the style and position of neck flexion for a long time have a relationship to the occurrence of mechanical neck pain. Posture most often leads to postural stress on the cervix is a sitting position with poor posture, where there is a sitting position with the head in a protruded position. ${ }^{2}$

The effect of the mechanism of post-isometric relaxation and reciprocal inhibition can cause the effects of relaxation reflex and changes in tolerance of stretch in the muscle because the organ tendencies around the muscle that experience lesions will be activated by post-isometric relaxation. Golgi tendon organs have inhibitor properties. $^{2}$ Golgi organ tendons will stimulate afferent nerve impulses and will enter the dorsal root of the spine and react with motor neuron inhibitors. ${ }^{14}$ The nature of these inhibitors can affect motor neurons in the muscles, causing a decrease 
in tension or muscle tone. Reciprocal inhibition utilizes antagonistic muscle contraction. Activation of contractions in antagonistic muscles will have an effect on muscle agonists, namely inhibition of muscle tone. This inhibitory effect will cause the agonist muscle (spasm muscle) to experience a relatively rapid tone reduction after contracting., ${ }^{2,14}$ Increased joint motion occurs because a decrease in muscle tone can eliminate restrictive barriers. ${ }^{2}$ The muscle energy technique's effect on the increased joint motion is given a contraction effect and stretches to produce viscoelastic changes. ${ }^{14}$

Muscle energy technique reduces pain by increasing stretch tolerance. MET involves central and peripheral modulatory mechanisms, such as muscle and joint mechanoreceptor activation involving centralized mediation pathways, such as the periaqueductal gray (PAG) or non-opioid serotonergic and noradrenergic inhibitory pathways. Activation of non-opioid descending inhibitory pathways will result in sympathoxecitation and activation from the lateral and dorsal periaqueductal gray (PAG). In addition, MET can improve fluid drainage and increase muscle stretch tolerance (hypoalgesia). Blood flow and lymph that leads to the muscle will increase due to the effects of rhythmic muscle contraction. Transcapillary blood flow will increase and interstitial pressure will also change as a result of mechanical force applications on connective tissue, more precisely on fibroblast. The application of MET can reduce pro-inflammatory cytokines and reduce the sensitivity of peripheral nociceptors. This reduces pain, makes stretching repeated easier and more tolerable. ${ }^{17}$ Static stretching on muscle energy technique can inhibit the Golgi tendon of the organ, thereby reducing motor neuron release. This causes relaxation of the musculotendinous units by resetting the resting length and modification of the Pacini corpuscle. This reflex will reduce musculotendinous tension and reduce pain perception. ${ }^{14}$

Muscle energy techniques can also be used to treat shortened muscles, weakened muscles, restricted joints, and lymphatic drainage. ${ }^{17}$ Fyrer (2011) in his journal entitled Muscle energy technique: An evidence approach states that muscle energy technique is effective in increasing extension and muscle length. The duration of the stretch phase must be considered in order to get better results. In chronic muscle shortening, the stretch phase should be carried out within 60 seconds. Longer stretching duration will be more effective than shorter duration, with 15 seconds more effective than 5 seconds and 30 seconds more effective than 15 seconds and so is 60 seconds.
The duration of 60 seconds shows better results compared to the shorter duration in parents with tight hamstring conditions, where these results are also representative of the shortening conditions of the fibrotic muscles. The shorter duration can be used to avoid tissue damage, encourage repair and healing. For a painless approach to chronic muscle shortening, medium contraction and stretching can be given, where stretching is done in 60 seconds. ${ }^{17}$

Muscle energy technique can also apply joint mobilization. The joint to be mobilized must be positioned in its limited position (specifically in the three fields if you want to mobilize the cervical segment: flexion/extension, lateral flexion, and rotation). Contract the patient's muscles eccentrically (isotonic) in the opposite direction for 3-10 seconds. Between contractions, relax the patient for 2 seconds or more. During this relaxation period, positioning the joint is limited to the degree of new limitations. ${ }^{16}$ Repeated muscle contractions during the application of muscle energy technique can reduce passive congestion in the paraspinal muscles, as a result of blood pressure fluctuations and lymphatic pressure that push fluid throughout the body. This will drain the fluid containing the zygapophyseal joint and segmental muscle so that it can achieve changes in the range of joint motion and end-feel. ${ }^{18}$

The application of muscle energy technique to chronic and limiting joint conditions will involve a degree of limitation at the elastic point of the final range will burden and stretch the capsule and pericapsular structure to produce viscoelastic and reduce tissue stiffness. In the moderate level, it can be used to giving improvement in the postisometric hypoalgesia, stretch tolerance, and adequate tissue contraction. This application will help proprioceptive feedback and recruitment and controlled isotonic contractions to shorten over a ROM. High-velocity low amplitude (HVLA) may also be used at the end of the joint range. Giving HVLA will form cavitation and increase the gap of the joints in the short term, following the range of joint motion to optimally stretch the pericapsular tissue. $^{17}$

Besides, other method which is useful in the mechanical neck pain is deep transverse friction. Deep transverse friction is a massage technique that can be used to reduce pain and is often used in musculoskeletal inflammatory conditions. ${ }^{19}$ this technique was developed by James Cyriax to maintain soft tissue mobility such as ligaments, muscles, tendons and must be applied in a specific transverse direction on tissues that have lesions. ${ }^{13}$

Deep transverse friction has three main effects, namely traumatic hyperemia, which helps reduce 
pain that triggers metabolites, the movement of tissue that has lesions, which prevents or destroys the formation of adhesions and helps optimize the quality of scar tissue, and stimulates the mechanoreceptors, which produce quantities afferent nerves which will stimulate transient analgesic effects. Deep transverse friction must be applied specifically to tissues that have lesions to give effect to scar formation. Deep transverse friction is given transversely with the direction of muscle fibers. Avoid glide movements on the skin because it can cause damage to the skin. Deep transverse friction begins with a smooth motion on the surface of the skin towards the opposite direction of the muscle fibers, then given emphasis and perform the friction phase in the lesion tissue. The depth of application of deep transverse friction corresponds to the depth of the tissue that has lesions. ${ }^{20}$

Deep transverse friction is enough to be given frequency three times a week with a duration of 1015 minutes. If in the case of chronic, deep transverse friction can be done for 20 minutes. If there is more than one area of the lesion, deep transverse friction can be done for 10 minutes in each lesion tissue. Indications for the administration of deep transverse friction are conditions of lesions in muscles, tendons, and ligaments. ${ }^{20}$ Deep transverse friction is also recommended as the treatment of choice for tendon injuries, such as tennis elbow, tendinitis, and pain. ${ }^{21}$ However, it has a contraindication, such as calcification, rheumatoid tendinous lesion, local sepsis, and skin disease. ${ }^{20}$

Research conducted by Mane et al (2017) states that deep transverse friction helps reduce pain and spasms/tightness and increase ROM of the neck joint. While Puspitaningrum (2014) states the results that deep transverse friction affects in reducing pain. Research conducted by Ladopurab (2012) explains that deep transverse friction can reduce pain. This is also supported by Mirawati's research, et al (2017) states that deep transverse friction has a pain reduction effect. Besides, studies conducted by Khan et al (2015) suggest that deep transverse friction is effective in improving flexion, extension, lateral flexion and rotation of the neck and reducing pain.

Deep transverse friction helps in reducing pain $^{13,19,22,23}$ and improves the range of joint motion. ${ }^{13,21}$ It is also can reduced pain through pain modulation in the level of supraspinal, which can release endorphins, enkephaline and cortisol. ${ }^{19,22}$ Application of deep transverse friction pressure on spasmic muscles will destroy the attachment of scar tissue so myofascial tissue will decrease. This will increase blood vessel flow and reduce the pain felt in the muscles that experience spasms/tightness. ${ }^{23}$
Deep transverse friction can also increase muscle relaxation so that the range of joint motion will increase. $^{13}$

\section{Conclusion}

Based on the literature review, it can be concluded that. Either muscle energy technique or deep transverse friction are shown a good effect to reduce pain, neck disability, and increase ROM of the cervical joint in patients with mechanical neck pain. Besides, deep transverse friction has also reducing spasm/tightness at the cervical joint level in patients with mechanical neck pain.

\section{CONFLICT OF INTEREST}

The authors have no conflict of interest with any commercial party.

\section{ACKNOWLEDGEMENT}

The authors want to thank the lecturers and the head of Department of Physical Therapy Udayana University, Bali, Indonesia for the discussion that have been given to authors during writing this article.

\section{AUTHOR CONTRIBUTIONS}

IPMP conceived the study design and literature reviewed and drafted the manuscript; HMSN and NWT drafted the manuscript and literature reviewed.

\section{REFERENCES:}

1. Gharib NMM, Hamid NS. Prevalence of mechanical neck pain in taif university female student : a survey study. J Am Sci. 2013;9(6):347-54.

2. Sudaryanto, Sutjana DP, Irfan M. Pemberian teknik mulligan dan soft tissue mobilization lebih baik daripada hanya soft tissue mobilization dalam meningkatkan lingkup gerak sendi ekstensi, rotasi, lateral fleksi cervical pada mechanical neck pain. Sport Fitn J. Nopember. 2013;1(2):54-69.

3. Yadav H, Goyal M. Efficiacy of muscle energy technique and deep neck flexors training in mechanical neck pain a randomized clinical trial. Int $J$ Therap Rehab Research. 2015;4(1): 52-66.

4. Wadee An. Efficacy of muscle energy techniques versus myofascial release in management of patients with cervical myofascial pain. Int J Chemtch Research. 2017;10(2):468-76

5. Hoy DG, Protani M, De R, Buchbinder R. The epidemiology of neck pain. Best Practice \& Research Clinic Rheumat. 2010:783-92

6. Juliastuti. Perbedaan pengaruh pemberian auto stretching dan kinesio taping terhadap penurunan nyeri pada sindroma nyeri servikal et causa mechanical neck pain. Desember 2017;5(2):432-44

7. Cohen SP. Epidemiology, diagnosis and treatment of neck pain. Mayo Clin Proc. February 2015;90(2) : 284-99

8. Misailidou V, Malliou P, Beneka A, Karagiannidis A, 
Godolias G. Assessment of patient with neck pain : a review of definitions, selection criteria, and measurement tools. $J$ Chiro Med. 2010;4:49-59

9. Belgian Health Care Knowledge Centre. 2009. Non-specific neck pain: diagnosis and treatment. Accessed on : https:// kce.fgov.be/sites/default/files/atoms/files/d20091027356. pdf

10. Leeds Community Healthcare NHS Trust. 2012. Differential diagnosis for mechanical neck pain and neck pain with radiculopathy. Accessed on: https://www. leedscommunityhealthcare.nhs.uk/seecmsfile/?id=2531

11. Ricciotti E, FitzGerald GA. Prostaglandins and inflammation. Arterioscler Thromb Vasc Biol. Mei 2011;31(5):986-1000

12. Kras JV, Dong L, Winkelstein BA. The prostaglandin e2 receptor, ep2, is upregulated in the drg after painful cervical facet joint injury in the rat. Spine (Phila Pa 1976). 1 Februari 2013;38(3):217-222

13. Mane P. Pawar A. Warude T. Effect os myofascial release and deep transverse friction massage as an adjuct to conventional physyiteraphy in case unilateral upper trapezius-comparative study. Int J Sci Reseach. Maret 2017;6(3):644-7

14. Arthawan MAP. Wahyuni N. Artini IGA. Perbandingan intervensi muscle energy technique dan infrared dengan contract relax stretching dan infrared dalam meningkatkan lingkup gerak sendi leher pada pemain game online dengan myofascial pain syndrome otot upper trapezius di denpasar. Majalah Ilmiah Fisioterapi Indonesia. Mei 2017;5(2):14-7

15. Phadke A. Bedekar N, Shyam A, Sancheti P. Effect of muscle energy technique and static stretching on pain and functional disability in patients with mechanical neck pain: a randomized controlled trial. Hong Kong Physio J. 2016;35:5-11
16. Chaitow L, Crenshaw K. Fritz S, Fryer G, Liebenson C, Muscle energy techniques. $3^{\text {rd }}$ ed. Wolfaard S, editor. Elsevier Health Sciences; 2006

17. Fryer G. Muscle energy technique : an evidence-informed approach. International Int J Osteopath Med. 2001;14:3-9

18. Lenehan KL, Fryer G, McLaughin P. The effect of muscle energy technique on gross trunk range of motion. $J$ Osteopat Med. 2003;6(1):13-8

19. Puspitaningrum DK. 2014. Pengaruh deep transverse friction terhadap nyeri myofascial trigger point syndrome otot upper trapezius pada karyawan desain grafis. Skripsi Fisioterapi Universitas Muhammadiyah Surakarta.

20. CRYIAX Transverse friction massage. Accessed on: www. fisiokinesiterapia.biz/NewDownload/CyriaxB.pdf

21. Ladopurab. Penelitian pendahuluan : pengurangan nyeri miofasial otot rhomboideus mayor dengan terapi micro wave diathermy dan deep transverse friction. Majalah Kedokteran FK UKI. Maret 2012;28(1):10-9

22. Mirawati KS, Dewi AANTT, Sutadarma IWG. Kombinasi infrared dan contract relax stretching sama baiknya dengan kombinasi infrared dan deep transverse friction terhadap penurunan disabilitas leher kondisi tension-type headache pada aparatur sipil negara di kantor gubernur bali. Majalah Inlimah Fisioterapi Indonesia. Mei 2017;5(2):10-13.

23. Khan AA, Farooqui SI, Sumble S. Khan MU. Efficacy of deep friction massage and ultrasound in the treatment of upper trapezius spasm - a randomized control trial. J Med Dental Sci Research. 2015;2(12):30-4.

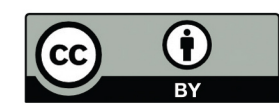

This work is licensed under a Creative Commons Attribution 